\title{
Evaluation of the hepatic NK cell response during the early phase of Fasciola hepatica infection in rats
}

\author{
Omar TlibA ${ }^{\mathrm{a}}$, Alain CHAuvin ${ }^{\mathrm{b}}$, Yves Le VerNc ${ }^{\mathrm{c}}$, Chantal Boulard ${ }^{\mathrm{a}}$, \\ Pierre SiBILLE*
}

\begin{abstract}
aUnité de Pathologie Aviaire et Parasitologie, INRA, 37380 Nouzilly, France
bUnité associée INRA/ENVN Interactions hôte-parasite-milieu, École Nationale Vétérinaire de Nantes, BP 40706, 44307 Nantes Cedex 03, France

'Service commun de Cytométrie de Flux, INRA, 37380 Nouzilly, France
\end{abstract}

(Received 2 October 2001; accepted 25 January 2002)

\begin{abstract}
The in situ distribution of NK cells in rat liver during the first 28 days of an experimental infection with $F$. hepatica was investigated. NK cells were distributed homogeneously throughout the hepatic parenchyma in uninfected animals. The total number of hepatic mononuclear cells increased significantly following infection, but the proportion of NK cells did not change. After infection, these cells were found around the portal space, around the centrolobular vein, in the periportal fibrosis and in the band of collagen. However, no NK cells could be detected in or around the granuloma during infection. The frequency of both IL-2- and IFN $\gamma$-producing NK cells was higher on day 7 postinfection (pi) but only the percentage of IFN $\gamma^{+} \mathrm{CD} 161^{+}$subsets remained elevated thereafter, whereas the percentage of both IL- $2^{+} \mathrm{CD} 161^{+}$and $\mathrm{IL}-4^{+} \mathrm{CD} 161^{+}$subsets returned to the baseline. The number of $\mathrm{CD} 161^{+} \mathrm{IL} 10^{+}$cells did not change significantly. These results suggest that NK cells could be another source for the early production of IFN $\gamma$ but provide no evidence that these cells are involved in early events associated with granuloma formation.
\end{abstract}

\section{Fasciola hepatica / NK cells / cytokine / flow cytometry / immunohistochemistry}

Résumé - Évaluation de la réponse des cellules NK hépatiques pendant la phase précoce d'infestation par Fasciola hepatica chez le rat. Nous avons suivi la localisation et la distribution hépatique des cellules NK durant les 28 premiers jours d'une fasciolose expérimentale chez le rat. Chez les animaux non infestés, les cellules NK sont distribuées de façon homogène dans tout le foie. Chez les animaux infestés, ces cellules sont localisées préférentiellement au niveau des espaces portes, autour des veines centrolobulaires, dans les bandes de collagène et dans la zone de fibrose périportale. En revanche, aucune de ces cellules n'a été détectée ni autour ni au sein du granulome. Le

*Correspondence and reprints

Tel.: (33) 2474277 47; fax: (33) 2474277 74; e-mail: sibille@tours.inra.fr 
pourcentage des cellules NK n'a pas changé durant l'infestation, en dépit de leur augmentation significative en nombre absolu. Tandis que la fréquence des cellules NK productrices d'IL-2 et d'IFN- $\gamma$ a augmenté au $7^{\mathrm{e}}$ jour après infestation, seule l'augmentation de celles qui produisent de l'IFN- $\gamma$ a persisté, la fréquence des cellules produisant l'IL-2 diminuant par la suite. Les cellules NK productrices d'IL-4 présentaient la même cinétique que l'IL-2, alors que celles qui produisent de l'IL-10 n'ont montré aucun changement. L'ensemble de ces résultats montre que les cellules NK constituent une autre source précoce d'IFN- $\gamma$, mais que leur participation à la formation précoce du granulome apparait peu probable.

\section{Fasciola hepatica / cellule NK / cytokine / cytométrie de flux / immunohistochimie}

\section{INTRODUCTION}

The common liver fluke, Fasciola hepatica, is a parasitic helminth which induces both acute and chronic infections in livestock and causes severe financial losses to farmers.

In contrast to the relatively low frequency of NK cells in the peripheral lymphatic system, they are quite abundant in the liver $[1,7]$. This has led to the hypothesis that optimal immune responses in the liver require the presence of NK cells. The role of these cells in the immune response has long been an area of intense interest since these cells may provide a first line of defence against invading infectious pathogens such as viruses, bacteria and parasites $[3,23]$ by exerting effector functions without having to be primed [9]. The activation of NK cells in response to certain pathogens involves an increased cytolytic capacity as well as the induction of cytokine production. Special attention was given to the cytokines, particularly IFN $\gamma$, which are produced by NK cells before T cell-derived cytokines are available. It has become increasingly clear that the early cellular and molecular events after infection are not only important for the regulation of the early defence against infection but also strongly influence the nature of the immune response and the ultimate outcome of disease $[14,19]$. Initially, using competitive RT-PCR, in $F$. hepatica experimentally infected rats, we observed that IFN $\gamma$ is up-regulated as early as 4 days postinfection (pi) and that the high levels of this cytokine were reached by 7 days pi [21]. The NK cells appear as a logical candidate for the production of IFN $\gamma$ at this stage of infection $[16,17]$. Thus, we aimed at following the early cytokine production by NK cells during the two first weeks after a primary $F$. hepatica infection in rats and to characterise their hepatic distribution.

\section{MATERIALS AND METHODS}

We used approximately 10 week old inbred Wistar rats of both sexes (reared at INRA, Nouzilly, France). Two groups of four rats were orally infected with 60 metacercariae [15] and killed by chloroform inhalation after 7 and 14 days of infection. One group of four healthy rats was not infected.

In order to locate the NK cells in hepatic parenchyma, we used Alcaline Phosphatase Anti Alcaline Phosphatase complex technique (APAAP) as previously described [20]. The optimal dilution of the mouse monoclonal antibody (mAb) 10/78, that recognises the CD161 molecule expressed on all rat NK cells (Serotec, Argène Varihles, France) [26], used for the immunohistochemistry assay was $1 / 50$.

Liver perfusion and cell preparation were performed as previously described [24]. The viability of the recovered cells was $>90 \%$. The purified HMNC were cultured with either $10 \mathrm{ng} / \mathrm{mL}$ PMA plus $0.5 \mu \mathrm{g} / \mathrm{mL}$ ionomycin and $2 \mu \mathrm{g} / \mathrm{mL}$ Brefeldin A (Sigma, 
Saint Louis, USA) for $18 \mathrm{~h}$ before being stained.

After culture, cells $\left(10^{5 / \text { tube })}\right.$ were washed with PBS containing 5\% of Fetal Calf Serum at $250 \mathrm{~g}$ for $7 \mathrm{~min}$, then, they were stained with $1 / 100$ dilution of $\mathrm{mAb}$ 10/78. After a $30 \mathrm{~min}$ incubation on ice, the cells were washed again and stained with $100 \mu \mathrm{L}$ of Donkey anti mouse Ig conjugated to Phycoerythrin (Interchim, Montluçon, France, 1/200 dilution). Before intracellular cytokine staining, the cells were fixed with $2 \%$ paraformaldehyde, permeabilised with $0.5 \%$ saponin (Sigma). IL-2, IL-4 and IL-10 staining was performed as previously described [22] by incubating cells with A38-3, B11-3B and A5-6 (Becton Dickinson, Le Pont de Claix, France; 1/50, $1 / 300$ and $1 / 50$ dilutions, respectively)
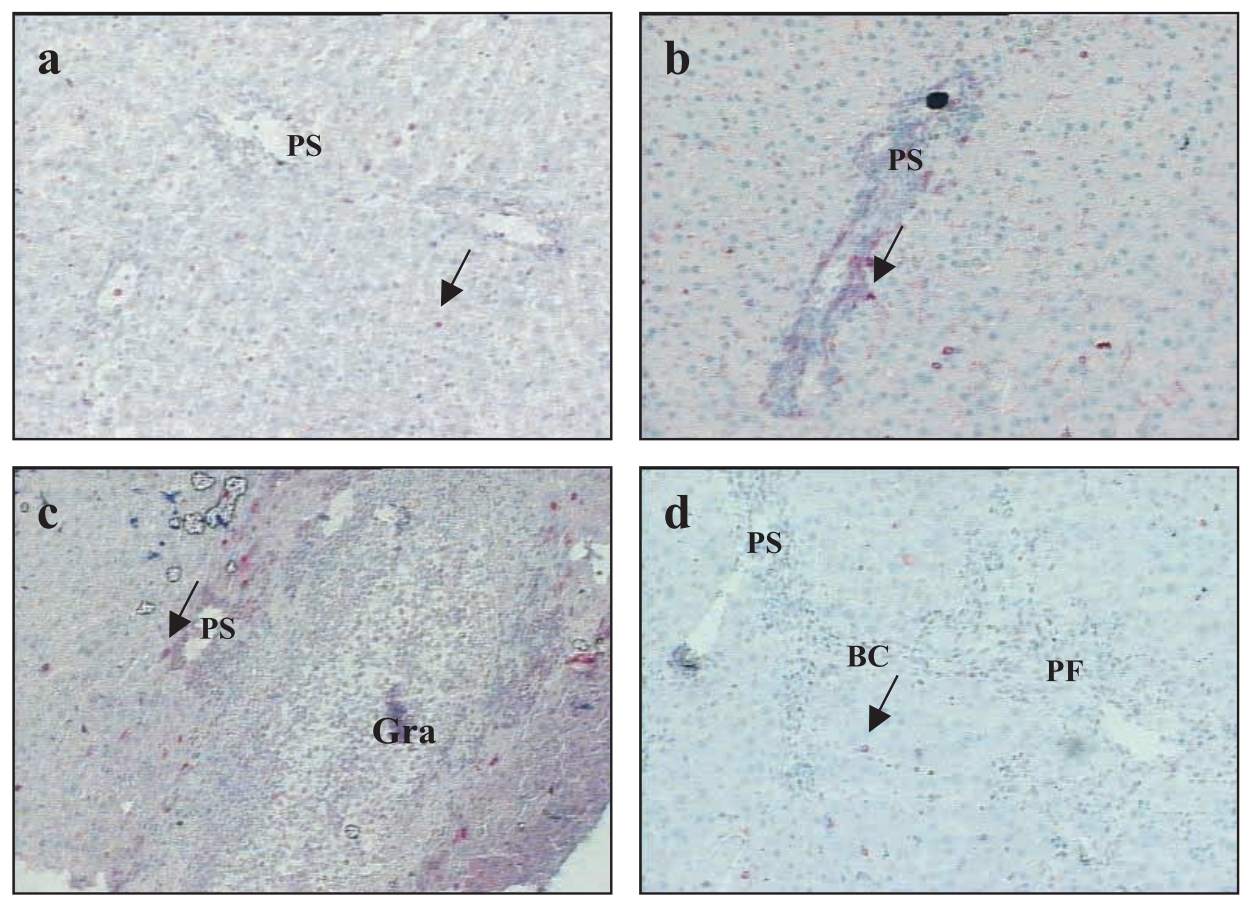

Figure 1. Immunohistological staining of frozen sections in hepatic parenchyma showing CD161 positive cells: (a) in an uninfected control animal $(\times 200)$, (b) at 7 days post infection $(\mathrm{DPI})(\times 200)$, (c) at 14DPI $(\times 200)$ and $(d)$ at 28DPI $(\times 200)$. PS: portal space, Gra: granuloma, PF: periportal fibrosis, BC: bands of collagen, arrow: NK cells. 
recruited recently (Fig. 1b). On days 14 and 28 pi, a few NK cells were observed in the periportal fibrosis and in collagen band (Figs. 1c and 1d) whereas no NK cells could be detected in or around the infection induced granuloma.

No significant change in the percentage of $\mathrm{CD} 161^{+}$cells could be observed, despite an increase in the total number of recovered NK cells (Tab. I). The frequency of IFN $\gamma$ producing NK cells was significantly higher on day 7 pi and remained elevated thereafter. In contrast, the proportion of IL-4-producing NK cells increased on day 7 pi but returned to the baseline one week later. The $\mathrm{CD} 161^{+} \mathrm{IL} 10^{+}$subset showed no significant change.

\section{DISCUSSION}

The present work showed no increase in the percentage of NK cells, whereas their absolute number was enhanced. This suggests that the recruitment of NK cells is non-selective and is related to the release of parasite products in the liver and/or to the local secretion of cytokines by the immune cells in this organ. We also demonstrated that the early increase of IFN $\gamma$ mRNA previously observed by RT-PCR [21] could be related, at least in part, to NK cells. Moreover, the increase in the production of different cytokines by NK cells (IL-2, IL-4 and IFN $\gamma$ ) on day 7 pi indicates that in vivo NK cell activity is higher than the baseline level during the early hepatic phase of $F$. hepatica infection in rats. This is in agreement with the results obtained by an other study which showed that NK activity was enhanced in mice infected with Trichinella spiralis [4]. Several molecules may act as positive regulators of $\mathrm{NK}$ cell function. IL-1, IL-2, IL-7, IL-12, IL-15, TNF $\alpha$, IFN $\alpha$ and IL-18 were reported to augment the production of IFN $\gamma$ by NK cells $[5,6,8$, $10-13]$. In vivo depletion of IL-12 substantially diminishes the NK cell activity response and/or early IFN $\gamma$ response in mice infected with Leishmania major and Trypanosoma cruzi [16, 18]. In addition, IL-12 can induce the co-production of Th1 and Th2 cytokines by human lymphoid cells [25]. This could account for the production of both IL-4 and IFN $\gamma$ by NK cells on day 7 pi. In $F$. hepatica infected rats, IL-12 mRNA increases as early as 4 days pi [21], however, the definitive role of these mediators in early trematode infection has yet to be demonstrated. Although the frequency of $\mathrm{CD} 161^{+} \mathrm{IFN} \gamma^{+}$cells remained high until day $14 \mathrm{pi}$, the Th2 response was clearly developed at this time of infection [21], suggesting that NK cells were not efficient at triggering the Th1 response.

The absence of NK cells in and around the granuloma suggests that these cells were not implied in the early phase of granuloma

Table I: Changes $\left( \pm\right.$ SEM) in the absolute numbers and percentage of hepatic CD161 ${ }^{+}$cells and their cytokine production during the early phase of infection with $F$. hepatica in rat.

\begin{tabular}{|c|c|c|c|c|c|c|}
\hline & \multirow{2}{*}{$\begin{array}{l}\text { No. of } \\
\text { CD161 } \\
\left(\times 10^{6}\right)\end{array}$} & \multicolumn{5}{|c|}{$\mathrm{CD} 161^{+}(\%)$} \\
\hline & & $\mathrm{CD} 161^{+}$ & $\mathrm{IL}^{+}$ & IFN- $\gamma^{+}$ & $\mathrm{IL}^{+}$ & $\mathrm{IL}^{+} 0^{+}$ \\
\hline Control & $2.26 \pm 0.57$ & $37.12 \pm 0.99$ & $15.40 \pm 0.42$ & $16.90 \pm 0.50$ & $24.87 \pm 0.70$ & $15.20 \pm 0.40$ \\
\hline 7 dpi infected & $* 3.84 \pm 0.28$ & $40.45 \pm 5.62$ & $* 19.42 \pm 2.70$ & $* 21.80 \pm 0.30$ & $* 34.78 \pm 4.80$ & $17.00 \pm 2.30$ \\
\hline 14 dpi infected & $* 5.09 \pm 0.92$ & $51.44 \pm 2.51$ & $10.00 \pm 0.50$ & $* 22.12 \pm 1.10$ & $27.78 \pm 1.40$ & $15.43 \pm 0.80$ \\
\hline
\end{tabular}

Each group contained at least four animals. The results are representative of three separate experiments. * Indicates $P<0.05$ compared to values in control. 
formation. However, in immunocompetent mice experimentally infected with Schistosoma mansoni, the NK cell depletion leads to an increase in hepatic collagen deposition in the late stages of granuloma formation [2]. This suggests that NK cells might have a regulatory function later on during $F$. hepatica infection.

This preliminary study needs to be completed by in vivo depletion of NK cells during early and chronic phase of fascioliasis in rat which should help us to elucidate the role of these cells in Th cytokine polarisation, their participation in the granuloma formation and in the development of the inflammatory response.

\section{REFERENCES}

[1] Abo T., Ohteki T., Seki S., Koyamada N., Yoshikai Y., Masuda T., Rikiishi H., Kumagai $\mathrm{K}$., The appearance of $\mathrm{T}$ cells bearing self-reactive t cell receptor in the livers of mice injected with bacteria, J. Exp. Med. 174 (1991) 417-424.

[2] Asseman C., Pancre V., Quatennens B., Auriault C., Schistosoma mansoni-infected mice show augmented hepatic fibrosis and selective inhibition of liver cytokine production after treatment with anti-nk1.1 antibodies, Immunol Lett. 54 (1996) 11-20.

[3] Bancroft G.J., The role of natural killer cells in innate resistance to infection, Curr. Opin. Immunol. 5 (1993) 503-510.

[4] Bany J., Janiak M.K., Budzynski W., Activity of natural killer (NK) cells in the course of experimental trichinellosis in mice, Wiad. Parazytol. 38 (1992) 117-126.

[5] Carson W.E., Ross M.E., Baiocchi R.A., Marien M.J., Boiani N., Grabstein K., Caligiuri M.A., Endogenous production of Interleukin 15 by activated human monocytes is critical for optimal production of Interferon-gamma by natural killer cells in vitro, J. Clin. Invest. 96 (1995) 2578-2582.

[6] Cooper M.A., Fehniger T.A., Ponnappan A., Mehta V., Wewers M.D., Caligiuri M.A., Interleukin-1 beta costimulates Interferon-gamma production by human natural killer cells, Eur. J. Immunol. 31 (2001) 792-801.

[7] Crispe I.N., Mehal W.Z., Strange brew: T cells in the liver, Immunol. Today 17 (1996) 522-525.

[8] Ghoneum M., Jewett A., Production of Tumor Necrosis Factor-alpha and Interferon-gamma from human peripheral blood lymphocytes by
MGN-3, a modified arabinoxylan from rice bran, and its synergy with Interleukin-2 in vitro, Cancer Detect. Prev. 24 (2000) 314-324.

[9] Herberman R.B., Natural killer cells, Hosp. Pract. (Hosp Ed). 17 (1982) 93-103.

[10] Jewett A., Bonavida B., Activation of the human immature natural killer cell subset by IL-12 and its regulation by endogenous TNF-alpha and IFN-gamma secretion, Cell. Immunol. 154 (1994) 273-286.

[11] Jewett A., Bonavida B., Interferon-alpha activates cytotoxic function but inhibits Interleukin2-mediated proliferation and Tumor Necrosis Factor-alpha secretion by immature human natural killer cells, J. Clin. Immunol. 15 (1995) 35-44.

[12] Kalina U., Kauschat D., Koyama N., Nuernberger H., Ballas K., Koschmieder S., Bug G., Hofmann W.K., Hoelzer D., Ottmann O.G., IL-18 activates SATA3 in the natural killer cell line 92, augments cytotoxic activity, and mediates IFN-gamma production by the stress Kinase p38 and by the extracellular regulated kinases p44erk-1 and p42erk-21, J. Immunol. 165 (2000) 1307-1313.

[13] Lu L., Zhou Z., Wu B., Xiao M., Shen R.N., Williams D.E., Kim Y.J., Kwon B.S., Ruscetti S., Broxmeyer H.E., Influence of recombinant human Interleukin (IL)-7 on disease progression in mice infected with friend virus complex, Int. J. Cancer. 52 (1992) 261-265.

[14] Orange J.S., Wang B., Terhorst C., Biron C.A., Requirement for natural killer cell-produced Interferon gamma in defense against murine cytomegalovirus infection and enhancement of this defence pathway by Interleukin 12 administration, J. Exp. Med. 182 (1995) 1045-1056.

[15] Poitou I., Baeza E., Boulard C., Analysis of the results obtained using a technique of experimental primary infestation with Fasciola hepatica in the rat, Int. J. Parasitol. 23 (1993) 403-406.

[16] Scharton T.M., Scott P., Natural killer cells are a source of Interferon Gamma that drives differentiation of $\mathrm{CD}^{+} \mathrm{T}$ cell subsets and induces early resistance to Leishmania major in mice, J. Exp. Med. 178 (1993) 567-577.

[17] Sher A., Oswald I.P., Hieny S., Gazzinelli R.T., Toxoplasma gondii induces a T-independent IFN-gamma response in natural killer cells that requires both adherent accessory cells and Tumor Necrosis Factor-Alpha, J. Immunol. 150 (1993) 3982-3989.

[18] Silva J.S., Aliberti J.C., Martins G.A., Souza M.A., Souto J.T., Padua M.A., The role of IL-12 in experimental Trypanosoma cruzi infection, Braz. J. Med. Biol. Res. 31 (1998) 111-115.

[19] Su H.C., Ishikawa R., Biron C.A., Transforming Growth Factor-Beta expression and natural killer cell responses during virus infection of 
normal, nude, and scid mice, J. Immunol. 151 (1993) 4874-4890.

[20] Tliba O., Sibille P., Boulard C., Chauvin A., Local hepatic immune response in rats during primary infection with Fasciola hepatica, Parasite 7 (2000) 9-18

[21] Tliba O., Sibille P., Boulard C., Chauvin A., Early hepatic cytokine mRNA expression in experimental rat fasciolosis, Vet. Parasitol. 103 (2002) 237-249.

[22] Tliba O., Moiré N., Le Vern Y., Boulard C., Chauvin A., Sibille P., Early hepatic immune response in rat infected with Fasciola hepatica, Vet. Res. 33 (2002) 261-270.

[23] Trinchieri G., Biology of natural killer cells, Adv. Immunol. 47 (1989) 187-376.
[24] Watanabi H., Ohtsuka K., Kiruma M., Ikarashi Y., Ohmori K., Kusumi A., Ohteki T., Seki S., Abo T., Details of an isolation method for hepatic lymphocytes in mice, J. Immunol. Methods 146 (1992) 145-154.

[25] Windhagen A., Anderson D.E., Carrizosa A., Williams R.E., Hafler D.A., IL-12 induces human T cells secreting ILl-10 with IFN-gamma, J. Immunol. 157 (1996) 1127-1131.

[26] Yokoyama W.M., Seaman W.E., The LY-49 and NKR-P1 gene families encoding lectin-like receptors on natural killer cells: The NK gene complex, Annu. Rev. Immunol. 11 (1993) 613635 .

To access this journal online: www.edpsciences.org 